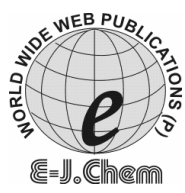

http://www.e-journals.net
ISSN: 0973-4945; CODEN ECJHAO

E-Journal of Chemistry

2009, 6(S1), S65-S74

\title{
A Comparative Study of the Corrosion Inhibitive Properties of Pyrimidine Derivatives for Mild Steel
}

\author{
P.SATHYA, K.PARAMESWARI ${ }^{*}$, S.CHITRA and A.SELVARAJ ${ }^{\#}$ \\ P.S.G.R.Krishnammal College for Women, \\ Peelamedu, Coimbatore-641004, Tamilnadu, India. \\ ${ }^{\#}$ CBM College, Coimbatore, Tamilnadu, India. \\ parampps@yahoo.co.in
}

Received 28 January 2009; Accepted 31 March 2009

\begin{abstract}
The influence of pyrimidine derivatives on the corrosion inhibition of mild steel in $1 \mathrm{M} \mathrm{H}_{2} \mathrm{SO}_{4}$ was studied using weight loss and electrochemical techniques. These compounds act as good corrosion inhibitors even at low concentration and the inhibition efficiency increased with the increase in inhibition concentration. The corrosion rates have been determined at various temperatures (303-333K) by weight loss measurements. The $R_{t}$ values obtained from EIS method increased with increase in inhibitor concentration. The potentiostatic polarization results clearly revealed that the inhibitors behave as a mixed type but slightly anodic in nature. The adsorption process was found to obey the Langmuir adsorption isotherm. The synergistic effect of halide ion on the inhibition efficiency increase with increase concentration.
\end{abstract}

Keywords: Pyrimidines, Inhibition, Adsorption isotherm, Impedence, Polarization, Double layer capacitance, Charge transfer resistance.

\section{Introduction}

The use of inhibitors is the most practical method of protection against corrosion, especially in acidic solutions. Their addition is necessary to secure the attack of metal from corrosive media used for chemical cleaning and pickling to remove mill scales (oxide scales) from the metallic surface ${ }^{1-6}$. Also inhibitors should be effective even under severe conditions in concentrated acid (1 M) and temperatures ranging from 313, 323 and $333 \mathrm{~K}^{7}$.

The development of corrosion inhibitors based on organic compounds has much scope in several industries because of their practical use. The molecular structure of organic compounds used as inhibitors has been found to exert a major influence on the extent of inhibition of corrosion. Inhibitors are used in industrial process to minimize both the metal loss and acid consumption. 
The corrosion inhibition of metal may involve either physisorption or chemisorption of the inhibitors to the metal surface and subsequent interference with either cathodic or anodic or both reactions occurring at the adsorption sites. The electrostatic attraction between the charged hydrophilic groups and the charged active centers on the metal surface leads to physisorption. The existing data show that most organic inhibitors adsorb on the metal surface and forming a compact barrier film ${ }^{8}$.

Moreover, many $N$-heterocyclic compounds have been proved to be effective inhibitors for the corrosion of metals and alloys in aqueous media. The influence of organic compounds containing nitrogen on the corrosion of steel in acidic solutions has been investigated by several authors ${ }^{9,10}$.

\section{Experimental}

Mild steel electrode having composition $0.084 \% \mathrm{C}, 0.369 \% \mathrm{Mn}, 0.129 \% \mathrm{Si}, 0.025 \% \mathrm{P}$, $0.027 \% \mathrm{~S}, 0.022 \% \mathrm{Cr}, 0.011 \% \mathrm{Mo}, 0.013 \% \mathrm{Ni}$ and the reminder iron were used. For weight loss and gasometric measurements, cold rolled mild steel rectangular specimens of size $5 \mathrm{~cm}$ $\times 2 \mathrm{~cm} \times 0.05 \mathrm{~cm}$ were used in this investigation.

For electrochemical methods, a mild steel rod of same composition with an exposed area of $0.785 \mathrm{~cm}^{2}$ was used. The electrodes were polished with $1 / 0,2 / 0,3 / 0$ and 4/0 grades of emery sheets and degreased with trichloroethylene. All the chemicals used were of AR grade. The compounds have been synthesized in two steps. 4, 6-diaryl-tetrahydropyrimidine2-thiones were synthesized according to the reported procedure ${ }^{11}$. Table 1 shows the molecular structure of the investigated compounds.

Table 1. Molecular Structure of the inhibitor.

Name and abbreviation
$\begin{gathered}\text { 4-Methyl-6-phenyl-tetrahydro } \\ \text { pyrimidine-2-thione, } \\ \text { THPT1 }\end{gathered}$
$\begin{gathered}\text { 4,6-Diphenyl-tetrahydro } \\ \text { pyrimidine-2-thione, } \\ \text { THPT2 }\end{gathered}$
4-Phenyl- 4a, 5, 6, 7, 8, 8a-hexahydro
quinazoline-2-thiol,
THPT3

\section{Inhibition Studies}

\section{Gravimetric measurements}

The specimens were polished successively with various grades of emery sheets, degreased with trichloroethylene and dried. Double distilled water and AR grade $\mathrm{H}_{2} \mathrm{SO}_{4}$ were used for preparing solutions. The specimens in triplicate were immersed in $1 \mathrm{M}$ acid solutions containing various concentrations of the inhibitor for three hours at $30 \pm 1{ }^{\circ} \mathrm{C}$. The specimens were removed washed with water and dried. The mass of the specimens before and after 
immersion was determined using an analytical balance accurate to $0.1 \mathrm{mg}$. The average mass loss of the three replicate measurements was calculated.

To study the effect of temperature, the weight loss experiments were carried out at various higher temperatures $v i z 40,50,60{ }^{\circ} \mathrm{C}$ with the inhibitor concentration of $0.1 \mathrm{~m} \mathrm{M}$. The following parameters were calculated from the mass loss data.

\section{Gasometry}

Polished and degreased mild steel specimens were suspended from a hook on a glass stopper and introduced into the gasometric cell containing $200 \mathrm{~mL}$ of the acid. From the volume of the gas collected in the absence and presence of the inhibitor, the inhibition efficiencies were calculated.

\section{Electrochemical impedance method}

Impedance measurements were carried out at the open circuit potential using the potentiostat (Solartron 1280B). In the conventional three-electrode assembly, a platinum foil auxiliary electrode and a saturated calomel electrode were used. The test specimen was used as working electrode. After immersion of the specimen prior to the impedance measurement, a stabilization period of 30 minutes was observed, for the $E_{o c}$ to attain a stable value. The ac frequency range extended from $10 \mathrm{KHZ}$ to $0.01 \mathrm{HZ}$, a $10 \mathrm{mv}$ peak-to-peak sine wave being the excitation signal. The real part Z' and imaginary part Z' of the impedance were measured at various frequencies. A plot of Z' vs. Z' was made and from these Nyquist plots, the charge transfer resistance $\mathrm{R}_{\mathrm{t}}$ and double layer capacitance $\mathrm{C}_{\mathrm{dl}}$ were obtained with a PC 'Z-view' soft ware. The measurements were carried out for mild steel in $1 \mathrm{M} \mathrm{H}_{2} \mathrm{SO}_{4}$ and $1 \mathrm{M}$ $\mathrm{HCl}$ without and with inhibitors for the selected concentrations and the IE was calculated using the formula

$$
\text { Inhibition efficiency }(\%)=\frac{\mathrm{R}_{\mathrm{t}(\mathrm{inh})^{-}} \mathrm{R}_{\mathrm{t}(\text { blank })}}{\mathrm{R}_{\mathrm{t}(\mathrm{inh})}} \times 100
$$

$R_{t(\text { inh) }}=$ Charge transfer resistance in the presence of inhibitor.

$\mathrm{R}_{\mathrm{t}(\text { blank })}=$ Charge transfer resistance in the absence of inhibitor.

\section{Tafel polarization measurements}

The same equipment was used, as for the impedance measurements with the same cell set up. Measurements were carried out at a potential range of $-200 \mathrm{mv}$ to $+200 \mathrm{mv}$ with respect to open circuit potential at a sweep rate of $1 \mathrm{mv} / \mathrm{sec}$. Potentials are reported versus that of the SCE. The $\log$ of current and the potential were fed to the plotter and a potential E vs $\log \mathrm{I}$ plot was obtained. The linear Tafel segments of the anodic and cathodic curves were extrapolated to corrosion potential to obtain corrosion current densities $\mathrm{I}_{\text {corr }}$. Tafel slopes were obtained using corr. view soft ware. The inhibition efficiency was evaluated from the measured $\mathrm{I}_{\text {corr }}$ values using the relationship,

$$
\text { Inhibition efficiency }(\%)=\frac{I_{\text {corr(blank) }} I_{\text {corr(inh) }}}{I_{\text {corr(blank) }}} \times 100
$$

Where $\mathrm{I}_{\text {corr(blank) }}, \mathrm{I}_{\text {corr(inh) }}$ are the corrosion current values without and with the addition of various concentration of inhibitor.

\section{Results and Discussion}

\section{Weight loss studies}

The inhibition efficiency with different concentrations of the inhibitors [THPT1, THPT2 \& THPT3] on mild steel in $1 \mathrm{M} \mathrm{H}_{2} \mathrm{SO}_{4}$ has been evaluated by weight loss measurements and 
the results are summarized in Table 2 and depicted in Figure 1. It is clear that the inhibition efficiency increases with increase in concentration. This behavior is attributed to the increase of the surface coverage $\theta$ due to adsorption of the inhibitor on the metal surface in the aggressive solution, which restricts the dissolution reaction. It is also evident that the inhibition efficiency increases in the order

\section{THPT2 > THPT3 $>$ THPT 1}

i.e. THPT2 with an additional phenyl ring at position 6 displayed maximum activity both at lower concentration $(0.02 \mathrm{~m} \mathrm{M})$ and at higher concentration $(0.1 \mathrm{~m} \mathrm{M})$ tested.

Table 2. Inhibition efficiencies of various concentrations of the inhibitors for corrosion of mild steel in $1 \mathrm{M} \mathrm{H}_{2} \mathrm{SO}_{4}$ obtained by weight loss measurement at $30 \pm 1{ }^{\circ} \mathrm{C}$.

\begin{tabular}{cccccc}
\hline $\begin{array}{c}\text { Name of the } \\
\text { inhibitor }\end{array}$ & $\begin{array}{c}\text { Concentra } \\
\text { tion, } \mathrm{m} \mathrm{M}\end{array}$ & $\begin{array}{c}\text { Weight } \\
\text { loss, } \mathrm{g}\end{array}$ & $\begin{array}{c}\text { Inhibition } \\
\text { efficiency, } \%\end{array}$ & $\begin{array}{c}\text { Degree of surface } \\
\text { coverage, } \theta\end{array}$ & $\begin{array}{c}\text { Corrosion } \\
\text { rate, mpy }\end{array}$ \\
\hline \multirow{6}{*}{ THPT1 } & Blank & 0.4845 & - & - & 7395.67 \\
& 0.02 & 0.3200 & 33.95 & 0.3395 & 4884.65 \\
& 0.04 & 0.2592 & 46.50 & 0.4650 & 3956.57 \\
& 0.06 & 0.2165 & 55.31 & 0.5531 & 3304.77 \\
& 0.08 & 0.1680 & 65.63 & 0.6563 & 2564.44 \\
THPT2 & 0.1 & 0.1163 & 75.99 & 0.7599 & 1775.26 \\
\hline & 0.02 & 0.2240 & 52.40 & - & 7183.50 \\
& 0.04 & 0.1790 & 61.96 & 0.5240 & 3419.26 \\
& 0.06 & 0.1268 & 73.05 & 0.6196 & 2732.35 \\
THPT3 & 0.1 & 0.0873 & 81.44 & 0.7305 & 1935.54 \\
& 0.0445 & 90.54 & 0.8144 & 1332.59 \\
& 0.02 & 0.2184 & 46.20 & 0.9054 & 679.27 \\
\hline & 0.06 & 0.1970 & 51.47 & 0.4620 & 6197.41 \\
& 0.08 & 0.1507 & 62.88 & 0.5147 & 3333.77 \\
& 0.1 & 0.0527 & 71.66 & 0.6288 & 2300.36 \\
\hline
\end{tabular}

This can be explained by assuming that the adsorption occurs with the entire molecule in flat orientation on the metal surface. In this planar adsorption the molecules get physically adsorbed through electrostatic interaction between positively charged metal surface and the lone pair of electrons on $\mathrm{N} \& \mathrm{~S}$ and also $\pi$ electrons of the aromatic ring.

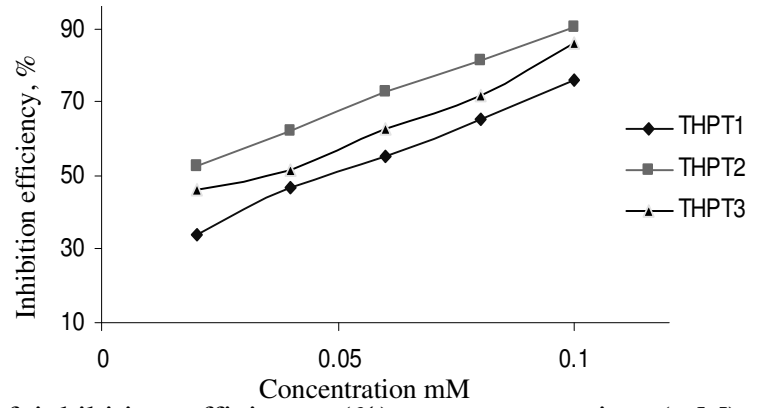

Figure 1. Plot of inhibition efficiency $(\%)$ vs concentration $(\mathrm{mM})$ for the inhibition of corrosion of mild steel in $1 \mathrm{M} \mathrm{H}_{2} \mathrm{SO}_{4}$. 
The greater inhibitive power of THPT2 may therefore be attributed to more $\pi$ electrons in the molecules because of the presence of an extra phenyl group in the compound.

\section{Effect of temperature}

The dissolution of metal and hence corrosion rate increases with rise in temperature $\left(30-60{ }^{\circ} \mathrm{C}\right)$ both in the presence and absence of inhibitor Table 3. The inhibition efficiency falls with increases in temperature in all the cases indicating physical adsorption. The activation energies were calculated from the slopes of Arrhenius plots Figure 2 for uninhibited and inhibited systems.

Table 3. Inhibition efficiencies of $10 \mathrm{~m} \mathrm{M}$ concentration of various inhibitors for corrosion of mild steel in $1 \mathrm{M} \mathrm{H}_{2} \mathrm{SO}_{4}$ obtained by weight loss measurement at higher temperatures.

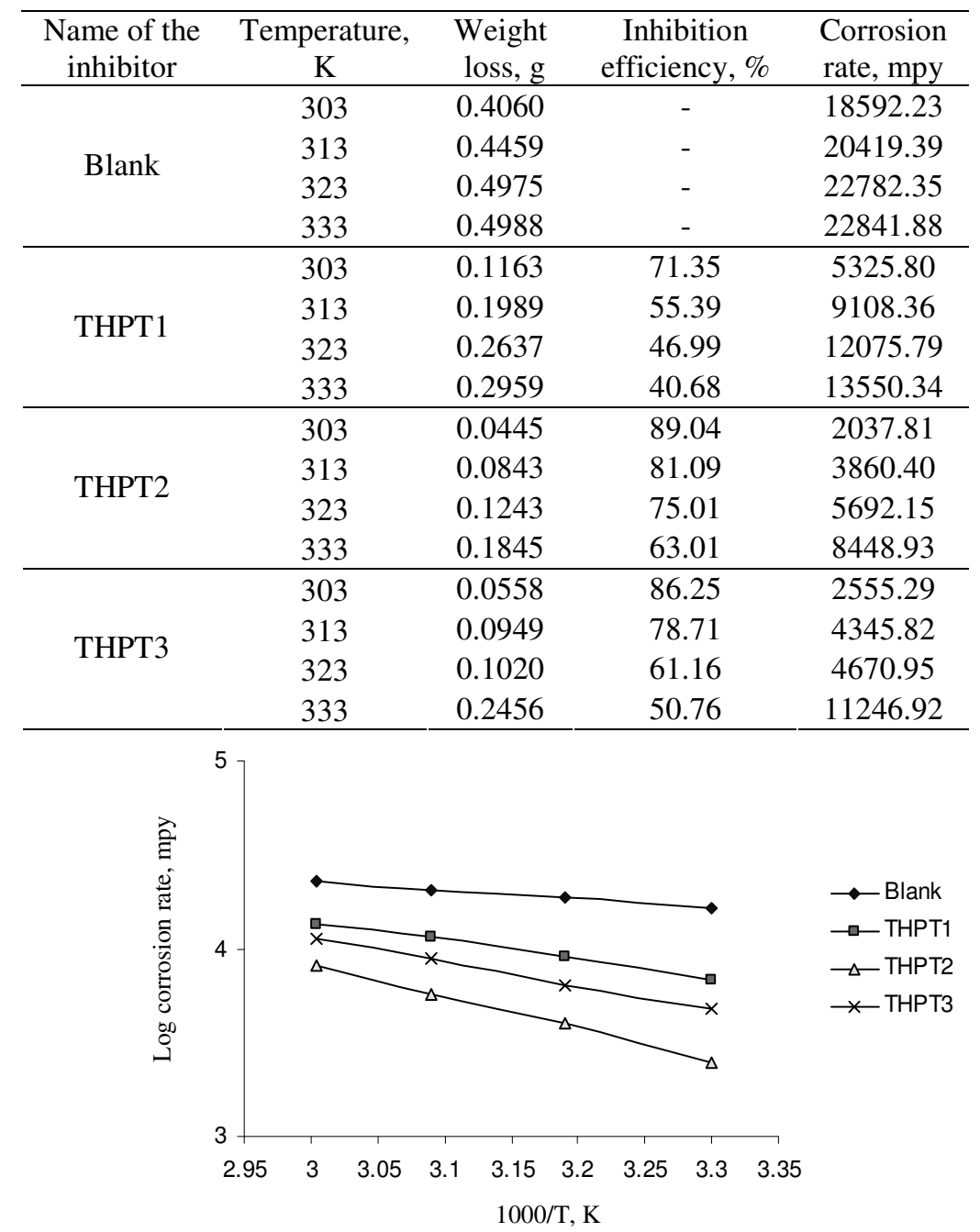

Figure 2. Arrhenius plot of corrosion rate of mild steel in $1 \mathrm{M} \mathrm{H}_{2} \mathrm{SO}_{4}$ solutions in the absence and presence of inhibitors. 
It is apparent from the values of $\mathrm{E}_{\mathrm{a}}$ Table 4 that the activation energy is higher in the presence of inhibitor. This is because the organic compounds have reaction centres that can block the active sites for corrosion, resulting in increased activation energy.

Table 4. Activation energies $\left(\mathrm{E}_{\mathrm{a}}\right)$ and free energy of adsorption $\left(\Delta \mathrm{G}^{\circ}\right.$ ads $)$ for the corrosion of mild steel in $1 \mathrm{M} \mathrm{H}_{2} \mathrm{SO}_{4}$ at $10 \mathrm{~m} \mathrm{M}$ concentration of the inhibitors.

\begin{tabular}{cccccc}
\hline \multirow{2}{*}{$\begin{array}{c}\text { Name of the } \\
\text { inhibitor }\end{array}$} & \multirow{2}{*}{$\mathrm{E}_{\mathrm{a}} \mathrm{kJ}$} & \multicolumn{4}{c}{$\Delta \mathrm{G}_{\text {ads }}^{\circ}$ at various temperatures, $\mathrm{kJ}$} \\
\cline { 3 - 6 } & & $303 \mathrm{~K}$ & $313 \mathrm{~K}$ & $323 \mathrm{~K}$ & $333 \mathrm{~K}$ \\
\hline Blank & 9.17 & - & - & - & - \\
THPT1 & 19.40 & -18.22 & -17.01 & -16.65 & -16.45 \\
THPT2 & 33.11 & -21.19 & -20.23 & -19.92 & -18.96 \\
THPT3 & 24.42 & -20.54 & -19.85 & -18.19 & -17.58 \\
\hline
\end{tabular}

$\Delta \mathrm{G}_{\mathrm{ads}}$ is negative which is indicative of spontaneous adsorption and the values are less than $20 \mathrm{KJ} / \mathrm{mole}$ showing physical adsorption.

\section{Application of adsorption isotherm}

The values of surface coverage $\theta$ have been calculated using weight loss data for different concentrations of the inhibitors. Figure 3 shows plot of $\mathrm{C} / \theta$ vs $\mathrm{C}$ of the inhibitors. Linearity of these curves confirms that the adsorption is of the Langmuir type.

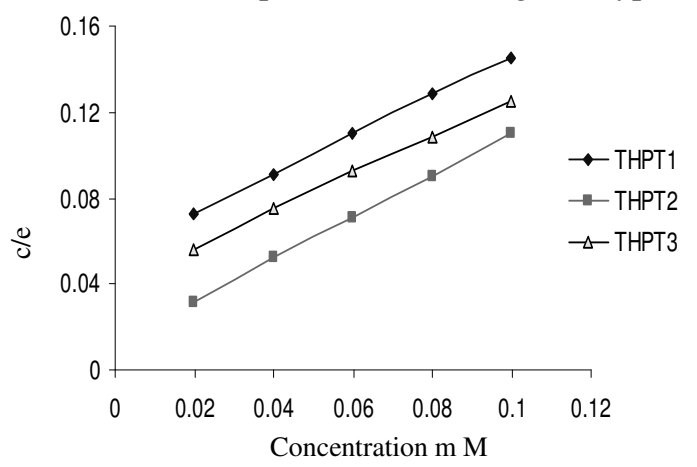

Figure 3. Langmuir plot of inhibitors in $1 \mathrm{M} \mathrm{H}_{2} \mathrm{SO}_{4}$

\section{Polarisation studies}

Various corrosion kinetic parameters such as corrosion current $\left(\mathrm{I}_{\text {corr }}\right)$, corrosion potential $\left(E_{\text {corr }}\right)$, anodic and cathodic Tafel slopes $b_{a}$ and $b_{c}$ derived from polarization curves Figure 4 are given in Table 5. Values of corrosion current decrease in the presence of inhibitors. Maximum reduction in current occurs in the presence of THPT2 showing its higher inhibition efficiency. $\mathrm{E}_{\text {corr }}$ value are shifted slightly to more negative values in the presence of THPT1.But slightly less negative values in the presence of THPT2 \& THPT3. THPT2 \& THPT 3 affect $b_{a}$ to a greater extent compared to $b_{c}$ therefore these two compounds behave as predominantly anodic while THPT1 is mixed type and affect both cathodic hydrogen evolution and anodic metal dissolution reaction.

Impedance diagrams obtained for mild steel in $1 \mathrm{M} \mathrm{H}_{2} \mathrm{SO}_{4}$ in the presence and absence of the compounds under study are shown in Figure 5. Impedance diagrams are semicircular in appearance which indicates that the corrosion of mild steel is controlled by a charge transfer process. The Impedance parameters such as $\mathrm{R}_{\mathrm{t}}, \mathrm{C}_{\mathrm{dl}}$ are derived from Nyquist plots and are given in Table 6 . 
Table 5. Corrosion parameters for corrosion of mild steel with selected concentrations of the inhibitors in $1 \mathrm{M} \mathrm{H}_{2} \mathrm{SO}_{4}$ by potentiodynamic polarization method.

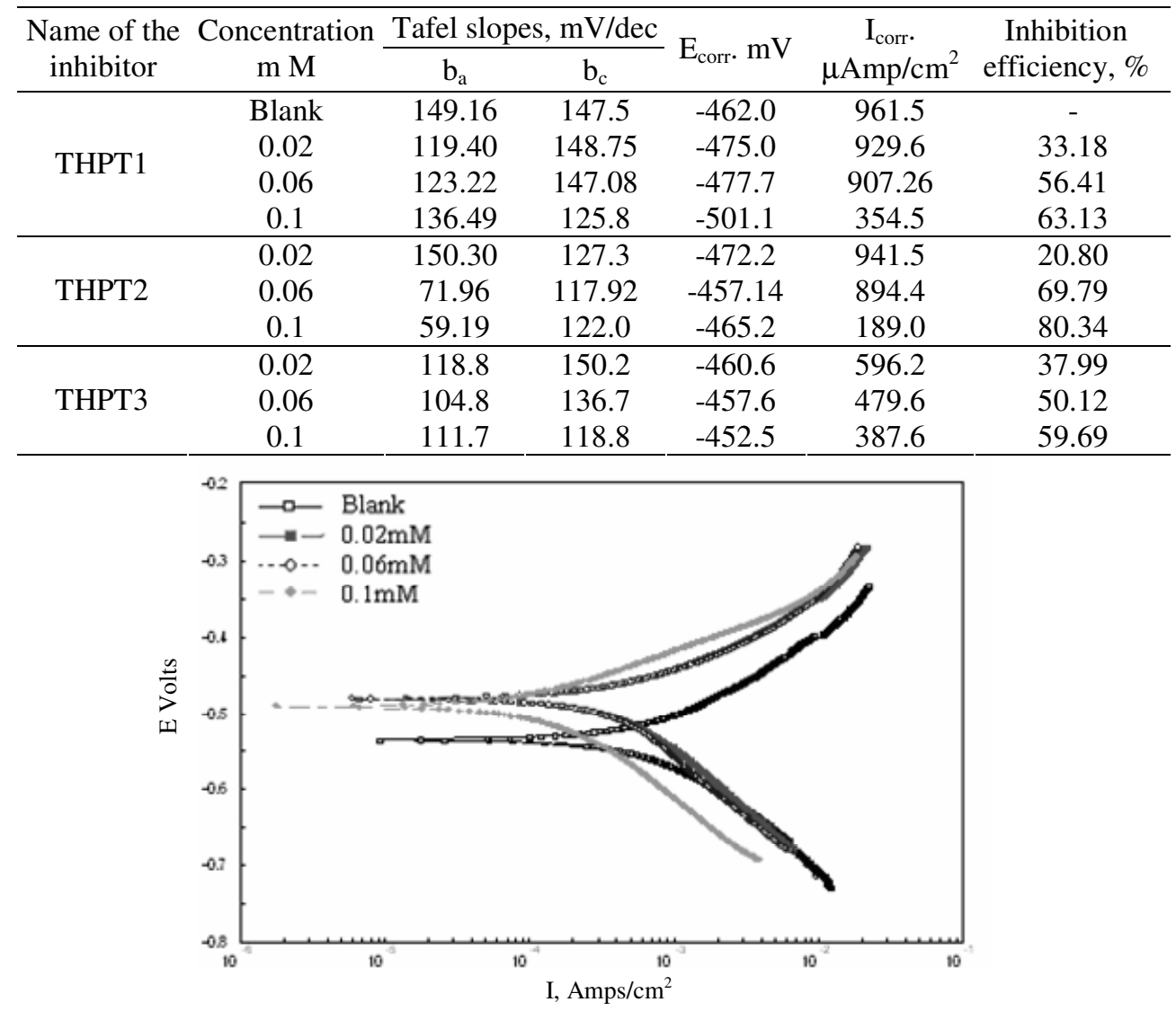

Figure 4. Polarization curves for mild steel recorded in $1 \mathrm{M} \mathrm{H}_{2} \mathrm{SO}_{4}$ for selected concentrations of inhibitor (THPT1).

\section{Impedance studies}

The presence of all the three compounds enhances the value of $\mathrm{R}_{\mathrm{t}}$. the values of double layer capacitance are also brought down in the presence of inhibitors. The decrease in $\mathrm{C}_{\mathrm{dl}}$ may be due to the adsorption of these compounds on the metal surface leading to the formation of a film.

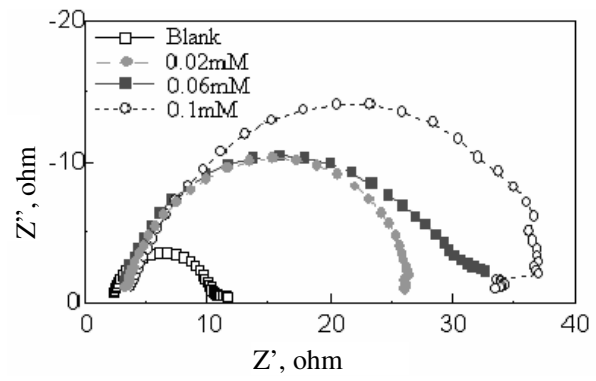

Figure 5. Nyquist diagram for mild steel in $1 \mathrm{M} \mathrm{H}_{2} \mathrm{SO}_{4}$ for selected concentrations of inhibitor (THPT1). 
Table 6. AC-impedance parameters for corrosion of mild steel for selected concentrations of the inhibitors in $1 \mathrm{M} \mathrm{H}_{2} \mathrm{SO}_{4}$.

\begin{tabular}{|c|c|c|c|c|}
\hline $\begin{array}{l}\text { Name of the } \\
\text { inhibitor }\end{array}$ & $\begin{array}{c}\text { Concentration, } \\
\mathrm{m} \mathrm{M}\end{array}$ & $\begin{array}{c}\mathrm{R}_{\mathrm{t}}, \\
\text { ohm cm }\end{array}$ & $\begin{array}{c}\mathrm{C}_{\mathrm{dl}}, \\
\mu \mathrm{F} / \mathrm{cm}^{2}\end{array}$ & $\begin{array}{c}\text { Inhibition } \\
\text { efficiency, \% }\end{array}$ \\
\hline \multirow{4}{*}{ THPT1 } & Blank & 8.2817 & 38.6210 & - \\
\hline & 0.02 & 22.6201 & 17.8080 & 63.39 \\
\hline & 0.06 & 33.22763 & 16.1772 & 75.11 \\
\hline & 0.1 & 36.5900 & 15.8270 & 77.37 \\
\hline \multirow{3}{*}{ THPT2 } & 0.02 & 33.1580 & 28.0380 & 75.02 \\
\hline & 0.06 & 35.1580 & 26.0060 & 76.59 \\
\hline & 0.1 & 56.7808 & 16.2056 & 85.41 \\
\hline \multirow{3}{*}{ THPT3 } & 0.02 & 18.7596 & 38.6710 & 55.85 \\
\hline & 0.06 & 30.6614 & 35.7251 & 72.98 \\
\hline & 0.1 & 46.2619 & 14.3470 & 82.09 \\
\hline
\end{tabular}

\section{Gasometry}

The inhibition efficiencies of the compounds have been calculated by gasometric method by measuring the volume of hydrogen gas evolved, over a period of one hour and the results are shown in Table 7. Increasing the concentration of additives decreased the volume of hydrogen evolved which indicates that the presence of inhibitors reduced the corrosion of mild steel.

Table 7. Inhibition efficiencies for the selected concentrations of the inhibitors for the corrosion of mild steel in $1 \mathrm{M} \mathrm{H}_{2} \mathrm{SO}_{4}$ obtained by gasometric measurement at $30 \pm 1{ }^{\circ} \mathrm{C}$.

\begin{tabular}{cccc}
\hline $\begin{array}{c}\text { Name of the } \\
\text { inhibitor }\end{array}$ & $\begin{array}{c}\text { Inhibitor } \\
\text { concentration, m M }\end{array}$ & $\begin{array}{c}\text { Volume of gas, } \\
\text { cc }\end{array}$ & $\begin{array}{c}\text { Inhibition } \\
\text { efficiency, \% }\end{array}$ \\
\hline & Blank & 27.0 & - \\
THPT1 & 0.02 & 17.8 & 34.07 \\
& 0.06 & 12.3 & 54.44 \\
THPT2 & 0.1 & 6.60 & 75.56 \\
\hline \multirow{2}{*}{ THPT3 } & 0.02 & 13.0 & 51.85 \\
& 0.06 & 6.90 & 74.45 \\
& 0.1 & 2.50 & 90.74 \\
\hline
\end{tabular}

\section{Synergistic effect of halide ions}

In the actual practical application of corrosion inhibitors, single compounds are rarely used, rather formulations of two or more inhibitors are usually employed ${ }^{12}$. The inhibition efficiency of organic compounds in sulphuric acid solutions has been reported to synergistically increase on addition of halide salts to the solution ${ }^{13}$.

In the present study the synergistic inhibition of halide ions and two pyrimidine derivatives (THPT1 \& THPT2) have been studied by weight loss method and the data are presented in Table 8 . It is evident that addition of halides $(1 \mathrm{~m} \mathrm{M})$ to the inhibitors increases the inhibition at each of the concentrations of the inhibitor tested.

The increase in inhibition efficiency shows that the mechanism of synergistic action is due to the co adsorption of halides and the inhibitor. The strong chemisorption of halide ions on mild steel surface makes the iron surface into a negatively charged one. Organic compounds 
containing nitrogen in aqueous acidic solutions may exist as either neutral molecules or in the form of cations. The positively charged protonated cations may then be adsorbed by coulombic attraction on the metal surface where halide ions are already adsorbed. This leads to more surface coverage and hence greater inhibition. Similar explanation has been proposed by Warraky et al. for the synergistic inhibition of benzotriazole or thiourea and iodide ion on the corrosion of Al- bronze ${ }^{14}$.

Table 8. Synergistic effect of $1 \mathrm{mM} \mathrm{KCl} / \mathrm{KBr} / \mathrm{KI}$ on the inhibition efficiency of THPT1 and THPT 2 by weight loss method at $30 \pm 1{ }^{\circ} \mathrm{C}$

\begin{tabular}{cccccc}
\hline \multirow{2}{*}{$\begin{array}{c}\text { Name of the Concentration, } \\
\text { inhibitor }\end{array}$} & $\mathrm{m} \mathrm{M}$ & $\begin{array}{c}\text { Without KCl, } \\
\text { KBr and KI }\end{array}$ & $\begin{array}{c}\text { With 1 m M } \\
\text { KCl }\end{array}$ & $\begin{array}{c}\text { With 1 m M } \\
\text { KBr }\end{array}$ & With 1 m M \\
& 0.02 & 29.18 & 37.30 & 38.77 & 47.52 \\
\hline \multirow{3}{*}{ THPT1 } & 0.04 & 43.82 & 45.83 & 50.87 & 52.24 \\
& 0.06 & 54.53 & 54.87 & 57.58 & 58.64 \\
& 0.08 & 62.41 & 62.49 & 64.25 & 65.13 \\
& 0.1 & 75.99 & 75.20 & 78.05 & 79.25 \\
\hline \multirow{2}{*}{ THPT2 } & 0.02 & 69.38 & 72.35 & 77.72 & 80.05 \\
& 0.04 & 76.84 & 78.06 & 81.08 & 86.64 \\
& 0.06 & 84.45 & 86.20 & 85.54 & 87.39 \\
& 0.08 & 88.93 & 87.65 & 90.12 & 91.80 \\
& 0.1 & 90.54 & 93.89 & 96.94 & 97.84 \\
\hline
\end{tabular}

The order of synergism of halide ions with the pyrimidines has been found to be,

$$
\mathrm{I}^{-}>\mathrm{Br}^{-}>\mathrm{Cl}^{-}
$$

The reason for better synergism with iodide ion is due to the large size and ease of polarizability of $\mathrm{I}^{-}$ion which facilitates chemisorptions on the iron surface.

\section{Effect of cations on the inhibition efficiency of pyrimidines}

It has been reported that addition of metal ions such as $\mathrm{Zn}^{2+}, \mathrm{Ni}^{2+}$ etc to organic compounds containing $\mathrm{N}$ and $\mathrm{S}$ leads to synergistic inhibition performance. The metal ions form stable complexes with the inhibitor on the mild steel surface and there by enhancing the surface coverage and inhibition.

The synergistic effect due to the addition of $\mathrm{Zn}^{2+}, \mathrm{Ni}^{2+}$ and $\mathrm{Mg}^{2+}$ on the corrosion performance of THPT1\& THPT2 has been studied by weight loss method in $1 \mathrm{M} \mathrm{H}_{2} \mathrm{SO}_{4}$. $1 \mathrm{mM}$ Concentration of $\mathrm{Zn}^{2+}, \mathrm{Ni}^{2+}$ and $\mathrm{Mg}^{2+}$ were used. Inhibitor concentration was varied from 0.02 $0.1 \mathrm{~m} \mathrm{M}$. The results are given in Table 9. The inhibition efficiency depends on the metal ion and also on the molar ratio of the inhibitor and metal ion. With THPT1, addition of $\mathrm{Zn}^{2+}$ and $\mathrm{Mg}^{2+}$ decreases the efficiency of the inhibitor. While with $\mathrm{Ni}^{2+}$ salts the inhibition efficiency is greatly increased at low inhibitor concentration but decreased with increase in concentration. With diphenyl tetrahydropyrimidine THPT2 $\mathrm{Zn}^{2+} \& \mathrm{Mg}^{2+}$ increased the inhibition efficiency to above $98 \%$ at $0.1 \mathrm{~m} \mathrm{M}$ concentration of inhibitors. Where as $\mathrm{Ni}^{2+}$ showed the same trend as with THPT1

These results show that the metal complexes of THPT1 are less stable where as the $\mathrm{Zn}^{2+}$ \& $\mathrm{Mg}^{2+}$ complexes of THPT2 are more stable giving greater inhibition efficiency. Similar explanation was offered for the effective corrosion inhibition by combination of $\mathrm{Zn}^{2+} \& \mathrm{Ni}^{2+}$ and pimeloyl-1, 5-dihydroxamic acid on carbon steel surface. It has also been reported that magnesium has no effect on the inhibitor efficiency as its complex has low stability constant ${ }^{15}$. In the present study contradictory results were obtained in that the $\mathrm{Mg}^{2+}$ complex of THPT2 shows higher inhibition efficiency $(99.41 \%)$ indicating the greater stability of the complex. 
Table 9. Effect of metal ions on the inhibition efficiency of THPT1 and THPT2 by weight loss method at $30 \pm 1{ }^{\circ} \mathrm{C}$.

\begin{tabular}{cccccc}
\hline \multirow{2}{*}{$\begin{array}{c}\text { Name of the } \\
\text { inhibitor }\end{array}$} & $\begin{array}{c}\text { Concentration } \\
\mathrm{m} \mathrm{M}\end{array}$ & \multicolumn{4}{c}{ Inhibition efficiency, \% } \\
\cline { 3 - 6 } & 0.02 & $\begin{array}{c}\text { Without } \mathrm{Zn}, \\
\mathrm{Ni} \text { and } \mathrm{Mg}\end{array}$ & $\begin{array}{c}\text { With } 1 \mathrm{mM} \\
\mathrm{Zn}^{2+}\end{array}$ & $\begin{array}{c}\text { With } 1 \mathrm{mM} \\
\mathrm{Ni}^{2+}\end{array}$ & $\begin{array}{c}\text { With 1mM } \\
\mathrm{Mg}^{2+}\end{array}$ \\
\hline \multirow{3}{*}{ THPT1 } & 0.04 & 43.82 & 20.81 & 91.53 & 22.52 \\
& 0.06 & 54.53 & 31.69 & 89.70 & 28.31 \\
& 0.08 & 62.41 & 43.25 & 79.37 & 40.12 \\
& 0.1 & 75.99 & 52.96 & 76.25 & 68.16 \\
& 0.02 & 69.38 & 58.05 & 91.89 & 29.77 \\
THPT2 & 0.04 & 76.84 & 60.83 & 74.38 & 50.16 \\
& 0.06 & 84.45 & 72.55 & 55.54 & 73.99 \\
& 0.08 & 88.93 & 82.22 & 39.53 & 81.49 \\
\hline
\end{tabular}

Inhibition concentration: $1 \mathrm{~m} \mathrm{M}$

\section{Conclusions}

The inhibitive effect of pyrimidine derivatives on the corrosion of mild steel in $1 \mathrm{M} \mathrm{H}_{2} \mathrm{SO}_{4}$ was carried out by weight loss, gasometric, electrochemical methods. The synthesized compounds were effective inhibitors because of the presence of hetero atoms $(\mathrm{N})$ and $-\mathrm{SH}$ groups that can cause effective adsorption process leading to the formation of an insoluble protective surface film which suppress the metal dissolution reaction. For the inhibitors tested, the inhibition efficiency increases with increase in inhibitor concentration. The adsorption of inhibitor on the mild steel surface obeys Langmuir adsorption isotherm. The efficiency decreases with rise in temperature. The Tafel slopes obtained from potentiodynamic polarization curves indicate that all the inhibitors behave predominantly as anodic type in $1 \mathrm{M} \mathrm{H}_{2} \mathrm{SO}_{4}$ and the inhibitor concentration causes a positive shift in corrosion potential.

\section{References}

1. Elachouri M, Hajji M S, Kertit S, Essasi E M, Salem M and Coudert R, Corros Sci., 1995, 37, 381.

2. Mernari B, Elattari H, Traisnel M, Bentiss F and Lagrenee M, Corros Sci., 1998, 40, 391.

3. Achouri M EI, Kertit S, Gouttaya H M, Nciri B, Bensouda Y, Perez L and Infante M R, Progress Org Coat., 2001, 43, 267.

4. Zucchi F, Trabanelli G and Brunoro G, Corros Sci., 1994, 36, 1683.

5. Cizek A, Mater Perform., 1994, 33, 56.

6. Frenier W W, Growcock F B, in Raman A and Labine P (Eds), Review on Corrosion Science and Technology, NACE International, Houston, TX, 1993, 11, 201.

7. Popova A, Sokolova E, Raicheva S and Christov M, Corros Sci., 2003, 45, 33.

8. Muralidharan S, Phani K L N, Pitchumani S, Ravichandran S and Iyer S V K, $J$ Electrochem Soc., 1995, 142, 1478.

9. Arshadi M R, Hasseini M G and Ghorbani M, Br Corr J., 2002, 37(1), 76.

10. Quafi A El, Hammouti B and Oudda H, Anti- Corros Methods Mater., 2002, 49(3), 199.

11. Ingle V N, Kharche S T and Upadhyay U G, Indian J Chem., 2004, 43B, 2027.

12. Hosary A A and Saleh R M, Progress in the Understanding and Prevention of Corrosion, Institute of Materials., 1993, 2, 911.

13. Gomma G K, Mater Chem Phy., 1998, 55, 241.

14. El Warraky A A and El-Dahan H A, J Mater Sci., 1997, 32, 3693.

15. Alagta A, Felhosi H, Telegdi Imre Betoti J and Kalman E, Corros Sci., 2007, 49 (6), 2754. 


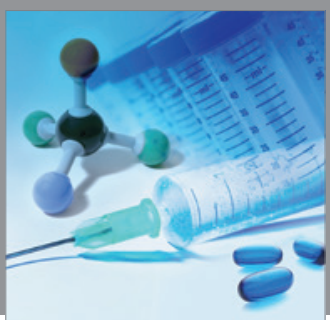

International Journal of

Medicinal Chemistry

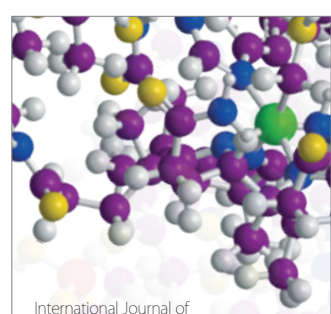

Carbohydrate Chemistry

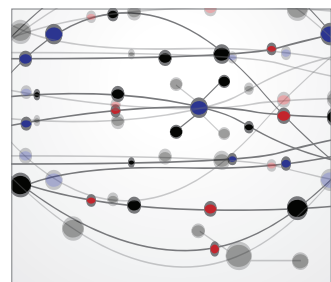

The Scientific World Journal
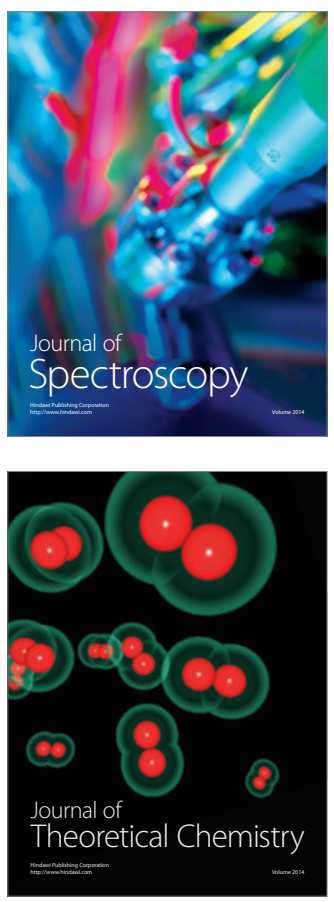
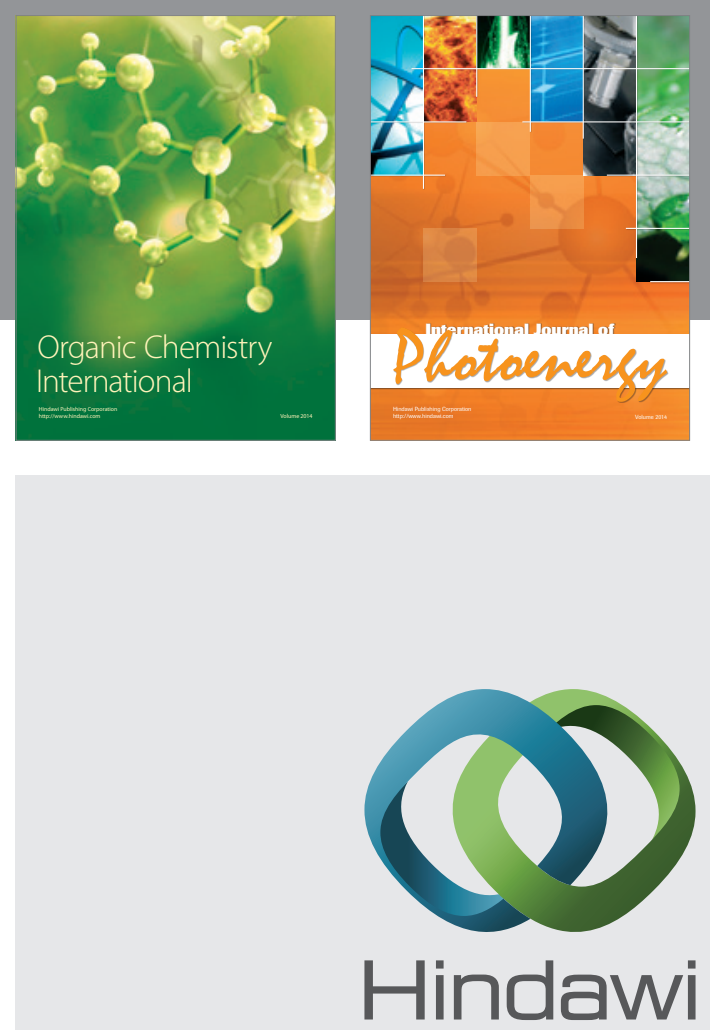

Submit your manuscripts at

http://www.hindawi.com
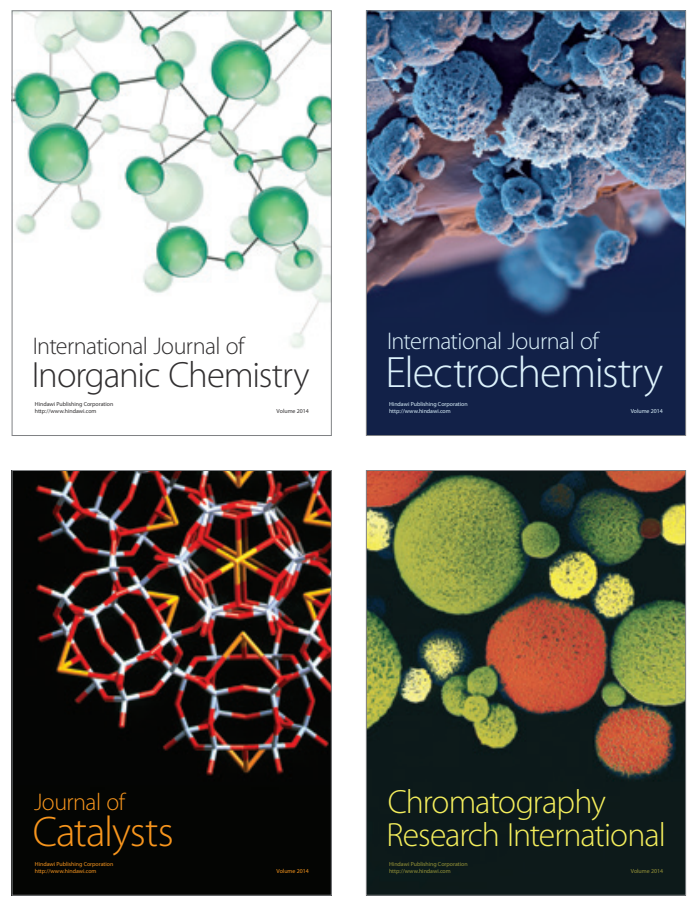
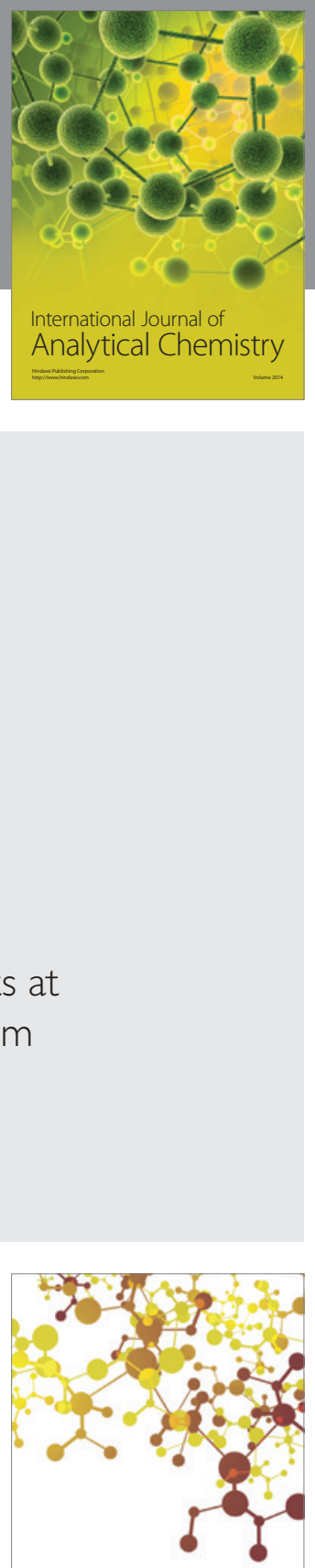

Journal of

Applied Chemistry
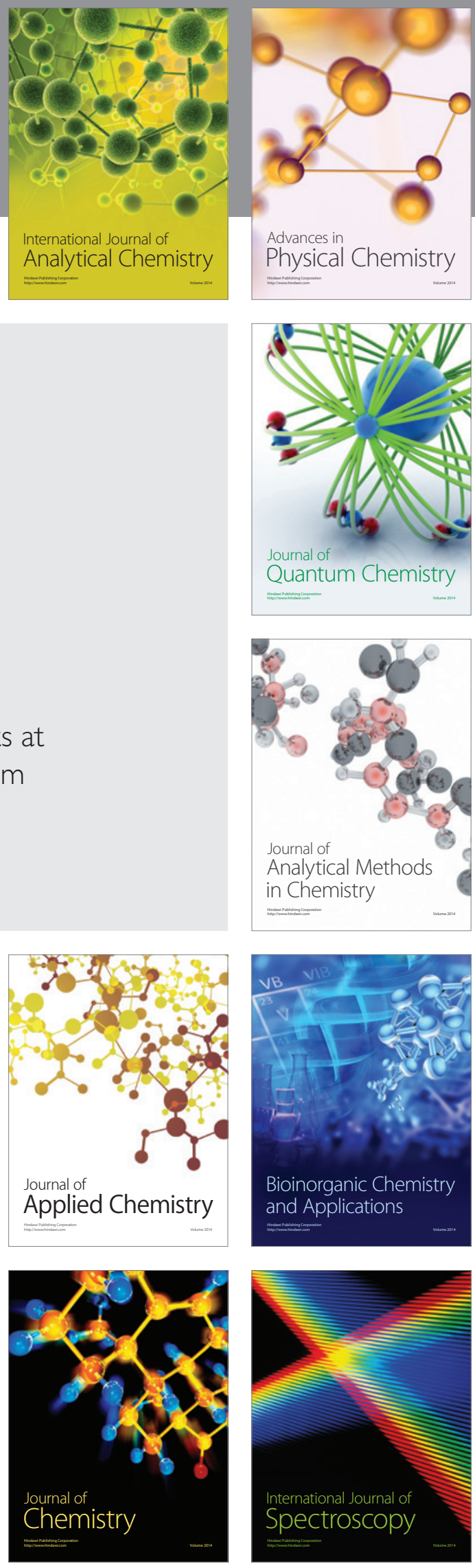